\title{
Principles of ensuring economic security
}

\author{
Alexander Nikolaevich Litvinenko*, Georgy Vartanovich Gioev, Yuri Vladimirovich \\ Gnezdilov, Maria Anatolyevna Podvoiskaya, and Aleksander Georgievich Sidenko
}

Saint Petersburg University of the Ministry of Internal Affairs of Russia, Department of Economic Security, Saint Petersburg, Russia

\begin{abstract}
The problem of economic security continues to remain relevant today, since the unstable, rapidly changing social and economic situation does not allow hoping for a quick solution to the institutional and infrastructural aspects of the development of economic systems. An important place in this issue is occupied by theoretical and methodological principles of ensuring economic security, the degree of development of which is still far from satisfactory. A review of regulatory documents and scientific papers on the principles of ensuring economic security indicates the dominance of the legislative and doctrinal approach. At the same time, systemic, process, situational approaches to the problem of economic security and the principles of its provision remain poorly studied and insufficiently developed. The purpose of the study is to substantiate the development feasibility of additional methodological tools, the core of which can be system, process, situational approaches, and the underlying principles along with the widespread legislative and doctrinal approach in the field of ensuring economic security. The proposed methodology based on systemic, process and situational approaches is based on principles that have proven themselves well in various branches of science. These principles are especially widespread in the theory and practice of both public administration and corporate management. The article proposes the principles of ensuring economic security, including the principle of increasing and orchestrated efforts, the principle of balance, and the principle of cyclical development, which can be useful in developing methodological measures defined in the Economic Security Strategy of the Russian Federation for the period till 2030.
\end{abstract}

Keywords: system approach, cyclicity, balance

\section{Introduction}

The problem of economic security covers many unsolved problems ranging from the formation of a special terminology or language for special purposes to the study of institutional and infrastructural aspects of the development of economic systems. An important place in this issue is occupied by theoretical and methodological principles of ensuring economic security at the geo, macro-, meso- and micro-levels, the development of which is still far from satisfactory.

*Corresponding author: gioev_g@mail.ru 
A legislative-doctrinal approach [1], based on the so-called "written law" ("jus scriptum") became widespread in the field of economic security. At the international level, this approach is implemented in the discussion and adoption of resolutions on the problems of geoeconomics (E. Luttwak): "Abandonment of coercive economic measures" (UNCTAD, 1983), "Economic measures as means of political and economic coercion in relation to developing countries" (GA UN, 1983), "On confidence-building measures in international economic relations" UN General Assembly (1984), "International Economic Security" (UN General Assembly, 1985, 1987). So, in the resolution of the "International economic security" 40th session of the UN General Assembly of December 17, 1985, it is proposed to develop a report on the Concept of international economic security and on the ways and means of achieving it. At the same time, the conviction is expressed that "...closing the gap in the levels of economic development" of developing countries is "one of the factors of international economic stability...” [2].

At the macro level, the legislative-doctrinal approach finds expression in the principles enshrined in the main law - the Constitution of the Russian Federation, but without referring them to the economic security field ( 8 formulations of principles): in the preamble - equality and self-determination of peoples; in Art. 15. cl. 4, Art. 17. cl. 1, Art. 69. cl. 1 - international law; Art. 72. cl. "i", Art. 75 cl. 3 - taxation and fees; Art. 72. cl. "n" - Establishment and local government arrangement; cl. 6 in Art. 75 - universality, justice and solidarity of generations; Art. 77 - organizations of representative and executive bodies of state power; in Art. 114 - social partnership and in Art. $131 \mathrm{cl} .1$ - the arrangement of local government [3].

There is also a commitment to the legislative and doctrinal approach indicated when developing principles for ensuring economic security at the mesa (micro) level. For example, the order of the Ministry of Economy of the Republic of Tatarstan dated June 6, 2016, No. 181: legality, economic feasibility, a combination of preventive and reactive measures, continuity, differentiation, coordination, full accountability of the system of ensuring economic security to the management of the organization [4].

Representatives of Russian science also pay attention to the development of theoretical principles for ensuring economic security. Makareiko, et al. [5], Fadeykina and Sinkina [6], Kurepina and Namrueva [7] and others devoted their works to the development and substantiation of the principles.

Thus, Makareiko identifies the following principles of ensuring economic security within the framework of the legislative-doctrinal approach: democracy, legality, humanism; equality before the law and subjects carrying out law enforcement activities in the field of economic security; a combination of centralization and decentralization; priority of preventive measures; economy of state coercion; operational flexibility; efficiency [8].

The works of foreign researchers are also devoted to the development of the theory and practice of ensuring economic security: Weizsäcker and Viikman [9], Ocepek [10], Andrusyak [11] and others.

\section{Methods}

The review of regulatory documents and scientific papers on the principles of ensuring economic security indicates the dominance of the legislative and doctrinal approach to their development. "The principles of ensuring economic security are undoubted of obvious legal value" [8]. At the same time, in our opinion, systemic, process, situational approaches to the problem of economic security and the principles of its provision remain poorly studied and insufficiently developed.

The above approaches have found their application in various branches of science and do not need to be demonstrated. Systemic, process, situational approaches in the theory and practice of both public administration and corporate management are especially widespread. 
In these spheres of government, several dozen principles of only public administration are open and systematized. So, Ponkin gives 39 principles while distributing them in 5 blocks: general legal and general political ( 8 units); general management ( 8 units); special (10 units); organizational (institutional) (8 units); cybernetic and hybrid (5 units) principles [12]. About 200 principles are found in corporate management manuals [13].

Let us consider the essence of the principle as a phenomenon, its role, and purpose. The principle (lat. Principium - the beginning, basis) is understood as the basic starting position of any theory, doctrine, worldview, political organization [14]; the main beginning on which something is built [15]; a guiding idea, a basic rule of conduct. In other words, in science, the principle plays the role of an initial, primary premise and is laid in the foundation of a particular scientific theory.

If we assume that the economic security of an economy object, be it a household, an enterprise, or a society, is a goal-setting value, then the subject of the economy needs to know, own, and apply the guiding principles of its provision for the successful implementation of the constitutional or other powers assigned to it.

\section{$3 \quad$ Results and discussion}

In this regard, the principles of ensuring economic security should be understood as guiding ideas that are in good agreement with the laws of being, that is, have similar characteristics with ontological categories. At the same time, each of the principles is a thesis that is approved and guided by the subject of the economic system, taking the achieved level of aggregate knowledge, experience, general and professional culture into account.

The first principle is the principle of increasing and coordinated efforts to achieve and strengthen economic security, arising from the dissipative nature of economic systems. Efforts are increasing because every economic system is subject to the inexorable influence of the 2nd law of thermodynamics, which means that it must tirelessly make efforts to neutralize and reverse the growth of entropy (R. Clausius). The coordination of efforts meets the requirements of the law of synergy, which multiplies the result due to the coordinated actions of its structural elements.

So, if we consider the results of a study conducted in 113 countries of the world on the level of accessibility and consumption of food, its availability, and sufficiency, the level of quality and safety, then this principle allows giving an objective assessment of the efforts of the subjects of the economic security system in the context of ensuring food security using the example of Russia and its eastern (China) and western (Belarus) neighbors (Table 1).

Table 1. Horizontal analysis of the dynamics of indices and ratings of world countries in terms of food security (sample)

\begin{tabular}{|c|c|c|c|c|c|c|c|}
\hline \multirow{3}{*}{ Countries } & 2016 & 2018 & 2019 & \multicolumn{2}{|c|}{ Rating growth } & \multicolumn{2}{|c|}{$\begin{array}{c}\text { Index growth rate, } \\
\%\end{array}$} \\
\cline { 2 - 8 } & $\begin{array}{c}\text { Ratings/ } \\
\text { Index }\end{array}$ & $\begin{array}{c}\text { Ratings/ } \\
\text { Index }\end{array}$ & $\begin{array}{c}\text { Ratings/ } \\
\text { Index }\end{array}$ & $\begin{array}{c}2018 \\
/ \\
2016\end{array}$ & $\begin{array}{c}2019 \\
/\end{array}$ & $\begin{array}{c}2018 \\
/ \\
2016\end{array}$ & $\begin{array}{c}2019 \\
/ \\
2018\end{array}$ \\
\hline Russia & $48 / 62.3$ & $42 / 67.0$ & $42 / 69.7$ & +6 & 0 & 7.54 & 4.03 \\
\hline China & $42 / 65.5$ & $46 / 65.1$ & $35 / 71.0$ & -4 & +9 & -0.61 & 9.06 \\
\hline Belarus & $46 / 63.1$ & $44 / 65.7$ & $36 / 70.9$ & +2 & +8 & 4.12 & 7.91 \\
\hline
\end{tabular}

Source: the table was compiled according to the Economist Intelligence Unit British research company [16] 
The principle of balanced development of individual parts of the subject should be considered as the second principle. The action of a complex of laws is manifested here: uneven development law, the least action law (A.A. Bogdanov), the law of composition and proportionality. The models of intersectoral balance (V.V. Leontyev), the balance of food resources, payment, trade, accounting, etc. are well known in the theory and practice of management. This principle allows ensuring the formation of an optimal, proportionate, harmonious mechanism for the development of the economic security system in the areas of planning, production, accumulation, distribution, consumption, accounting, and control. Thus, from the standpoint of this principle, it is possible to assess the balance of regional development, with the contribution of individual constituent entities of the Russian Federation to the growth of the country's gross value added (Fig. 1) being considered.
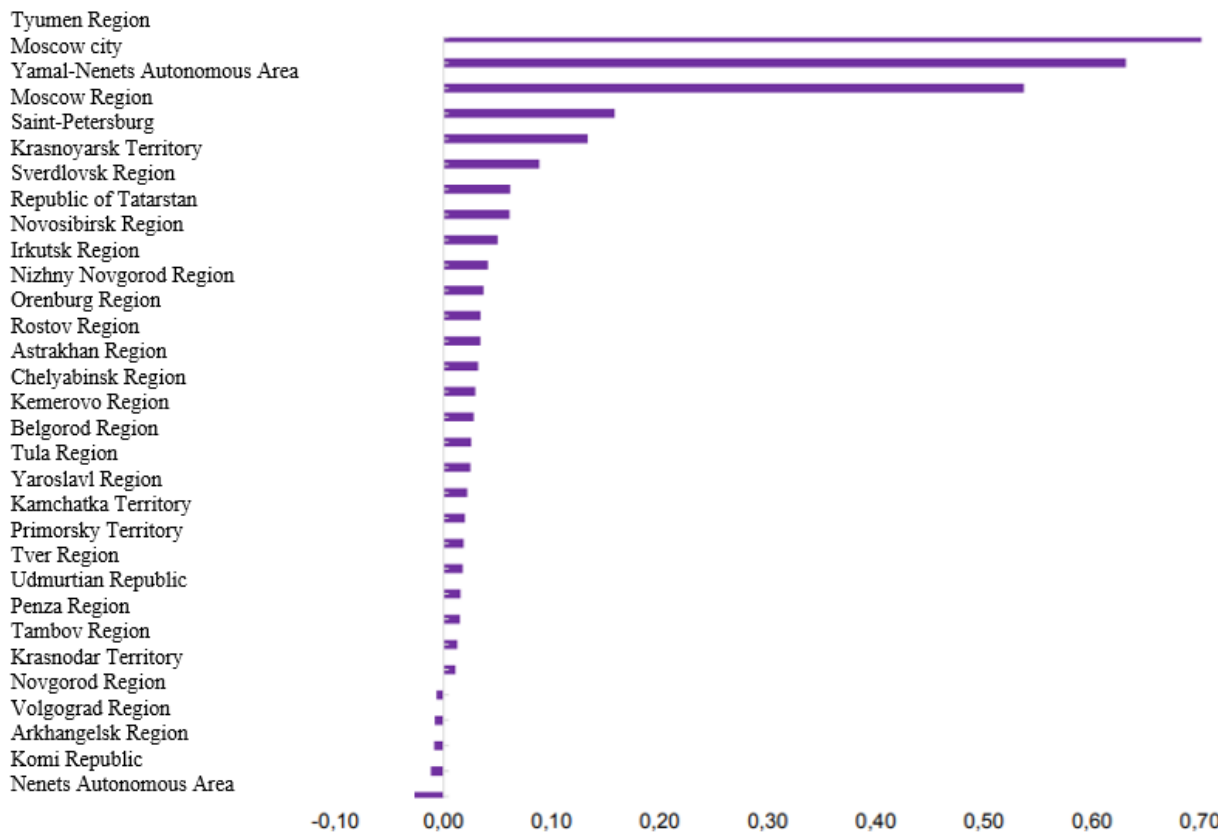

Fig. 1. Contribution of individual constituent entities of the Russian Federation to the growth of the country's gross value added in 2018. Source: Rosstat (according to the Bulletin on Current Trends in the Russian Economy) [17]

The principle of cyclical development based on the repeatability and returnability of invariants that are inherent in the economic security system like any other system should be considered as the third principle. According to this principle, it is necessary to distinguish between the stages of the life cycle of system objects, in which there are both unsteady processes in the periods of formation or in the stages of transition, and the trajectory of "sustainable development" (V.I. Vernadsky). Accordingly, at the stages of formation or change of the system, the role of the management subject objectively increases. The role of the state in the transitional periods of its historical development, which is entrusted by society to manage strategic and related sectors of the economy and strengthen the regulation of economic activity, is an example. And vice versa, with the onset of an era of stability, the state transfers part of its powers to other subjects of economic relations, stimulating business activity, expanding individual and collective forms of entrepreneurship.

\section{Conclusion}


The above provisions give reason to conclude that it is advisable to systematize and implement no less valuable systemic, process, and situational approaches along with the legislative and doctrinal ones in the practice of ensuring economic security. The principles of growing and orchestrated efforts, balance and cyclical development proposed in the article are not by any means the entire toolkit necessary to achieve state goals in the field of ensuring economic security, but they can be useful in developing methodological measures defined in the Economic Security Strategy of the Russian Federation for the period till 2030 [18].

\section{References}

1. A.V. Petryanin, O.A. Petryanina, Journal of Nizhny Novgorod Academy of the Ministry of Internal Affairs of Russia, 21, 173 (2013)

2. Resolution of the 40th Session of the UN General Assembly "International Economic Security", December 17, 1985, No. A/RES/40/173. Accessed on: October 22, 2020. [Online]. Available: https://www.un.org/ru/ga/40/docs/40res.shtml

3. Ofitsialnyi internet portal pravovoy informatsii [Official Internet Portal of Legal Information]. Accessed on: October 23, 2020. [Online]. Available: http://publication.pravo.gov.ru/Document/View/ 0001202007040001

4. Prikaz ministerstva ekonomiki Respubliki Tatarstan [Order of the Ministry of Economy of the Republic of Tatarstan], dated June 6, 2016, No. 181 "On approval of the approximate standard for the activities of economic security services of enterprises and organizations operating in the territory of the Republic of Tatarstan". [Online]. Access from the ConsultantPlus Reference Legal System

5. E.P. Simaeva, I.G. Tyutyunnik, Pravovoe regulirovanie promyshlennoy politiki Rossii s pozitsii privlecheniya inostrannykh investitsyi [Legal regulation of Russia's industrial policy from the perspective of attracting foreign investment] (Yustitsinform Publ., 2017)

6. N.V. Fadeikina, A.A. Sinkina, Siberian Financial School, 4(129), 38, (2018)

7. N.L. Kurepina, L.V. Namrueva, Bulletin of the South Russian State Technical University (NPI). Series: Socio-economic sciences, 4, 84 (2019)

8. N.V. Makareiko, Legal technique, 14, 231 (2020)

9. E.U. Von Weizsäcker, A. Wijkman, Come On! Accessed on: October 26, 2020. [Online]. Available: http://sg-sofia.com.ua/comeon-romeclub-2018

10. A. Ocepek, Economic Security and the European Dream. Accessed on: October 26, 2020. [Online]. Available: https://www.academia.edu/525483/Economic_Security_and_the_European_Dream

11. G. Andruseac, CES Working Papers 7(2), 232 (2015)

12. I.V. Ponkin, Teoriya publichnogo upravleniya [Theory of Public Administration] (Moscow, IGSU RANEPA, Buki Vedi Publ., 2017)

13. G.B. Gioev, Upravlenchesko-metodologicheskie aspekty formirovaniya infrastruktury organov vnutrennikh del [Management and methodological aspects of the formation of the infrastructure of the internal affairs bodies], Doctorial $\mathrm{PhD}$ thesis in Economics (Saint Petersburg State University of Economics, Saint Petersburg, 2019). Accessed on: October 24, 2020. [Online]. Available: https://unecon.ru/dis-sovety/fio-soiskatelyagioev-georgiy-vartanovich-0 
14. Slovar russkogo yazyka, t. 1, A-J [Dictionary of the Russian language: in 4 volumes, vol. 1, A.P. Evgenyeva, ed.] (Academy of Sciences of USSR, Institute of Russian Language, Moscow, Russkiy Yazyk Publ, 1985)

15. D.N. Ushakov (ed.), Tolkovyi slovar russkogo yazyka [Explanatory Dictionary of the Russian Language], vol. 2 (Moscow, Gos. Izd-vo Inostr. i Nats. Slovarey Publ., 1938)

16. Global Food Security Index (GFSI). Accessed on: October 25, 2020. [Online]. Available: https://foodsecurityindex.eiu.com/Index

17. Bulleten o tekushchikh tendentsiyakh rossiyskoy ekonomiki [Bulletin on Current Trends in the Russian Economy], 62, 10 (June 2020). Accessed on: October 22, 2020. [Online]. Available: https://ac.gov.ru/uploads/2-Publications/BRE_62.pdf

18. Ukaz prezidenta RF [Decree of the President of the Russian Federation, May 13, 2017 , "On the strategy of economic security of the Russian Federation for the period till 2030”, No. 208] [Online]. Access from the ConsultantPlus Reference Legal System 